\title{
High Temperatures Induce ROS Generation and Damage to Respiratory Activity in Saccharum officinarum Suspension Cells
}

\author{
Irina V. Lyubushkina ${ }^{a, b}$, Anna V. Fedyaevaa, \\ Aleksey V. Stepanov ${ }^{\mathrm{a}}$ and Olga I. Grabelnych ${ }^{\mathrm{a}, \mathrm{b} *}$ \\ ${ }^{a}$ Siberian Institute of Plant Physiology \\ and Biochemistry SB RAS \\ Irkutsk, Russian Federation \\ ${ }^{b}$ Irkutsk State University \\ Irkutsk, Russian Federation
}

Received 20.04.2021, received in revised form 29.05.2021, accepted 25.07.2021

\begin{abstract}
High temperatures are important abiotic stressors affecting plant growth, development and productivity. One of the consequences of unfavourable temperature effects on plants is an increase in reactive oxygen species (ROS) generation. However, what role ROS will play in the further fate of the cell under temperature stress depends on many external and internal factors. Therefore, the aim of this study was to identify the relationship between ROS content and mitochondrial function in the cells of a Saccharum officinarum suspension culture under high temperatures. The work was carried out using fluorescence microscopy and the polarographic analysis method. We found the most significant increase in ROS content in $S$. officinarum cells during temperature treatments (that did not cause immediate cell death in culture) was at 45 and $50^{\circ} \mathrm{C}$. The ROS content was largely determined by mitochondrial activity, as evidenced by a decrease in the electrochemical potential on the inner mitochondrial membrane $\left(\Delta \Psi_{\mathrm{m}}\right)$, and a simultaneous decrease of ROS levels in cells under the carbonyl cyanide m-chlorophenyl hydrazine (CCCP) treatment. The decrease in the respiratory activity of cells under high temperatures was determined by the decrease of the cytochrome pathway $(\mathrm{CP})$ contribution. It should be noted that the reduction in respiration rate at a temperature of $50{ }^{\circ} \mathrm{C}$ preceded the death of cells in the culture, and was not a consequence of it.
\end{abstract}

(C) Siberian Federal University. All rights reserved

This work is licensed under a Creative Commons Attribution-NonCommercial 4.0 International License (CC BY-NC 4.0).

* Corresponding author E-mail address: grolga@sifibr.irk.ru ORCID: 0000-0001-6692-4482 (Lyubushkina I.V.); 0000-0002-0637-6899 (Fedyaeva A.V.); 0000-0002-0456-3690 (Stepanov A.V.); 0000-0003-4220-6608 (Grabelnych O.I.) 
Keywords: Saccharum officinarum, high temperature stress, reactive oxygen species, electrochemical potential on the inner mitochondrial membrane, carbonyl cyanide m-chlorophenyl hydrazine, respiration.

Acknowledgements. The research was performed using the collections of The Core Facilities Center «Bioresource Center» and the equipment of The Core Facilities Center «Bioanalitika» at The Siberian Institute of Plant Physiology and Biochemistry SB RAS (Irkutsk, Russia).

Citation: Lyubushkina I. V., Fedyaeva A. V., Stepanov A. V., Grabelnych O. I. High temperatures induce ROS generation and damage to respiratory activity in Saccharum officinarum suspension cells. J. Sib. Fed. Univ. Biol., 2021, 14(3), 354-369. DOI: $10.17516 / 1997-1389-0355$

\title{
Повышенные температуры вызывают образование АФК
}

\section{и нарушения дыхания в клетках \\ суспензионной культуры Saccharum officinarum}

\author{
И. В. Любушкина ${ }^{a, 0}$, А. В. Федяева \\ А. В. Степанов ${ }^{\mathrm{a}}$, О.И. Грабельных ${ }^{\mathrm{a}, \boldsymbol{\sigma}}$ \\ ${ }^{a}$ Сибирский институт физиологии и биохимии растений СО РАН \\ Российская Федераичи, Иркутск \\ ${ }^{\sigma}$ Иркутский государственнылй университет \\ Российская Федерация, Иркутск
}

\begin{abstract}
Аннотация. Высокие температуры являются важными абиотическими стрессорами, влияющими на рост, развитие и продуктивность растений. Увеличение образования активных форм кислорода (АФК) - одно из последствий их негативного влияния. Однако то, какую роль сыграют АФК в дальнейшей судьбе клетки в условиях температурного стресса, зависит от множества внутренних и внешних факторов. Таким образом, целью данной работы стало выявление взаимосвязи между содержанием АФК и функционированием митохондрий в клетках суспензионной культуры Saccharum officinarum при действии повышенных температур. Данное исследование проводилось с использованием флуоресцентной микроскопии и полярографического анализа. Было обнаружено, что температуры 45 и $50^{\circ} \mathrm{C}$ вызывают значительное увеличение содержания АФК в клетках $S$. officinarum, что, тем не менее, не приводит к немедленной гибели клеток в культуре. Содержание АФК во многом определялось активностью митохондрий, о чем свидетельствует снижение электрохимического потенциала на внутренней митохондриальной мембране $\left(\Delta \Psi_{\mathrm{m}}\right)$ и одновременное снижение уровня АФК в клетках при обработке карбонилцианид-м-фенилгидразоном (СССР). Уменьшение дыхательной активности в клетках при высокотемпературном воздействии было обусловлено снижением вклада цитохромного пути (ЦП). Следует отметить, что снижение скорости дыхания при температуре $50{ }^{\circ} \mathrm{C}$ предшествовало гибели клеток в культуре, а не было ее следствием.
\end{abstract}


Ключевые слова: Saccharum officinarum, высокотемпературный стресс, активные формы кислорода, электрохимический потенциал на внутренней митохондриальной мембране, карбонилцианид-м-фенилгидразон, дыхание.

Благодарности. Работа выполнена с использованием коллекций ЦКП «Биоресурсный центр» и оборудования ЦКП «Биоаналитика» Сибирского института физиологии и биохимии растений СО РАН (г. Иркутск, Россия).

Цитирование: Любушкина, И.В. Повышенные температуры вызывают образование АФК и нарушения дыхания в клетках суспензионной культуры Saccharum officinarum / И. В. Любушкина, А. В. Федяева, А. В. Степанов, О. И. Грабельных // Журн. Сиб. федер. ун-та. Биология, 2021. 14(3). С. 354-369. DOI: 10.17516/1997-1389-0355

\section{Introduction}

Temperature is one of the most important environmental factor affecting the growth, development and productivity of plants. Since plants are sessile and cannot avoid stressful effects, they have formed various evolutionary physiological and biochemical adaptation mechanisms that ensure their survival under adverse conditions. High temperatures cause changes to cell membrane lipid contents, resulting in changes in physical and chemical characteristics (Djanaguiraman et al., 2018). They induce synthesis of specific proteins (heat stress proteins and dehydrins), secondary metabolites (phenolic and terpenoid compounds) and compatible osmolytes (water soluble sugars, polyoles, proline and glycine betaines) (Vierling, 1991; Graether, Boddington, 2014; Nievola et al., 2017). All these processes require significant energy costs, so the need for ATP increases under stress conditions.

Mitochondria are energy supply organelles in both heterotrophic and photosynthetic plant cells. The mitochondrial electron-transport chain (ETC) creates electrochemical potential on the inner membrane $\left(\Delta \Psi_{\mathrm{m}}\right)$ for the synthesis of ATP by ATP-synthase. The cytochrome pathway (CP) of respiration in plants (as in animals) contains four main complexes: NADH dehydrogenase (complex I), succinate dehydrogenase (complex II), cytochrome $c$ reductase (complex III) and cytochrome $c$ oxidase (complex IV). Electron transport in complexes I and III is accompanied by ROS generation (Møller, 2001). There is a superoxide anion $\left(\mathrm{O}_{2}{ }^{\circ}\right)$, which can be converted to $\mathrm{H}_{2} \mathrm{O}_{2}$ by a matrix-localised manganese superoxide dismutase (Morgan et al., 2008).

Under normal conditions, ROS are important secondary messengers and participants of plant cell signalling pathways, playing an important role in the integration and regulation of cellular metabolism, as well as in the formation of plant responses to environmental factors (Kohli et al., 2019). However, ROS are not only signal transduction molecules, but also toxic, highly active compounds. An increase in their content in cells above a critical level can cause the development of intracellular oxidative stress, accompanied by damage to lipids, proteins and nucleic acids (Kolupaev, Karpets, 2009; Dmitrieva et al., 2018; Tripathi et al., 2020).

Under adverse conditions, the formation of plant acclimatisation mechanisms to stress factors is very often accompanied by fluctuation in the energy status of cells and changes to the respiration process (Baena-González, Sheen, 2008). This can lead to an intensification of ROS generation in mitochondrial ETC. To 
protect respiratory metabolism, and to prevent over-reduction of ETC components, plant mitochondria contain an alternative pathway (AP) of respiration as well as the classical CP. This involves rotenone-insensitive II type $\mathrm{NAD}(\mathrm{P}) \mathrm{H}$ dehydrogenases, ubiquinone and alternative cyanide-resistant oxidase (AOX) (Wanniarachchi et al., 2018). Electron flow via the AP is not coupled with proton pumping, and energy obtained during substrate oxidation is dissipated as heat. ROS production decreases as the AP bypasses complexes I and III (the main points of ROS generation) (Noctor et al., 2007; Popov, 2014).

AOX is an additional terminal oxidase in plant mitochondria. It is located on the matrix side of the inner mitochondrial membrane and transfers electrons from ubiquinone to oxygen, bypassing two of the three points of electron and proton transport coupling. It has been shown that AOX is activated by limitation of $\mathrm{CP}$ electron transport and an elevated $\mathrm{NADH} / \mathrm{NAD}^{+}$ratio (Vanlerberghe, 2013). It has been stated that the role of AOX in plant respiratory metabolism significantly increases under stress conditions. High and low temperatures and drought can all lead to AOX activation (Bartoli et al., 2005; Grabelnych et al., 2014; Borovik, Grabelnych, 2018). It is possible that one of the functions of AOX is regulation of ROS production (Popov, 2014). This is supported by the fact that AOX is activated by mitochondrial thioredoxins that are involved in protecting these organelles from the toxic effects of ROS (Martí et al., 2009).

Suspension cell cultures of plants are practical, and are therefore frequently used as model objects for investigating plant cell responses to stress (Nguyen et al., 2016) and the processes of cell differentiation and death (Zavala-Ortiz et al., 2020). Despite the fact that the effect of high temperatures on plant metabolism is frequently studied today, including using suspension cell cultures (Rikhvanov et al., 2007), studies dealing with respiratory metabolism in plant suspension cell cultures under these conditions are very few. There are a number of studies regarding respiration in plant suspension cell cultures that are under stress caused by a lack of nutrients (Sieger et al., 2005) or the action of chemical agents, e. g. $\mathrm{H}_{2} \mathrm{O}_{2}$ (Robson, Vanlerberghe, 2002). However, the relationship between respiratory metabolism and ROS generation in the cells of suspension cultures is not well understood (Fedyaeva et al., 2014). Using an Arabidopsis thaliana cell culture, it has been shown that temperatures close to $40{ }^{\circ} \mathrm{C}$, i. e. 37 and $39^{\circ} \mathrm{C}$, acted on cells as a mild heat shock and promoted the formation of induced thermotolerance mechanisms (Rikhvanov et al., 2007). Our purpose was to study the effects of a hard heat shock on various parameters of cellular metabolism. Therefore, a number of high temperatures, from 45 to $60{ }^{\circ} \mathrm{C}$, were investigated. Considering the high thermotolerance of Saccharum officinarum, the cell culture of this species is a good model for studying the effect of high temperatures on the energy metabolism of plant cells and the role of cellular respiration under stress.

This study has shown the relationship between respiratory activity, $\Delta \Psi_{\mathrm{m}}$ and ROS levels in $S$. officinarum suspension culture cells for the first time. Differences between the various respiratory pathways functioning under high-temperature treatments that caused cell death in culture and did not have a lethal effect have been revealed. It has been shown that high temperatures caused ROS production to increase. This effect was dependent on the duration of treatment exposure and mitochondrial activity. High temperatures that led to cell death caused significant respiratory depression, mainly due to inhibition of the CP. 


\section{Materials and methods}

Plant material, growth conditions

and high temperature treatments

We used a suspension cell culture of Saccharum officinarum (cultivar POJ2878, line resistant to anoxia, obtained at IPP RAS and kindly provided by Shmakov V.N. (PhD, Senior Researcher of the Laboratory of Plant Genetic Engineering, SIPPB SB RAS)). Cell culture was grown using an MS medium, containing sucrose (36 g/L), nicotinic acid $(0.6 \mathrm{mg} / \mathrm{L})$, pyridoxine $(0.6 \mathrm{mg} / \mathrm{L})$, thiamine $(1.2 \mathrm{mg} / \mathrm{L}), 2.4-\mathrm{D}(3 \mathrm{mg} / \mathrm{L})$, inositol $(120 \mathrm{mg} / \mathrm{L})$ and potassium dithiocarbamate $(6 \mathrm{mg} / \mathrm{L})$. The culture was placed in a fresh medium every 14 days with a 1:7 dilution. The culture was grown in 200-mL Erlenmeyer flasks, in the dark and in a thermostatic chamber at $26^{\circ} \mathrm{C}$ with constant stirring on a rotary shaker at 130 rpm. After eight days of cultivation, the culture was subjected to high temperature treatments. The treatments $\left(45,50,55\right.$ and $\left.60^{\circ} \mathrm{C}\right)$ were carried out using a mini thermal shaker (TS-100, «BioSan», Latvia) and a water thermostatic shaker («Elpan», Poland). After each treatment, the culture was returned to controlled conditions $\left(26^{\circ} \mathrm{C}\right)$ for one, two or four days.

\section{Microscopic analysis}

Microscopic analyses of cells were performed using a light microscope (Axiostar plus, Carl Zeiss, Gottingen, Germany) and an inverted fluorescent microscope (AxioObserver Z1, Carl Zeiss) with a digital monochrome camera (AxioCam MRm3). The software package AxioVisionRel4.6 was used to capture and analyse images. We used the following filters: filter set 15 (EX BP 546/12, BS FT 580 and EM LP 590) and filter set 10 (EX BP 450-490, BS FT 510 and EM BP 565).

\section{Determination of cell survival}

The proportions of living and dead cells in the cultures were determined by double staining with fluorescent probes: vital fluorescein diacetate (FDA, $50 \mu \mathrm{M})$ and lethal propidium iodide (PI, $7 \mu \mathrm{M}$ ) (Lyubushkina et al., 2014b). Briefly, $100 \mu \mathrm{L}$ of culture was placed in $2 \mathrm{~mL}$ microcentrifuge tubes and incubated for $2 \mathrm{~min}$ at $26{ }^{\circ} \mathrm{C}$ (with the addition of dyes) on a TS-100 mini thermal shaker.

\section{ROS and $\triangle \Psi_{m}$ detection}

To detect ROS levels in the cells of the S. officinarum culture, we used a fluorescent sensor $\left(\mathrm{H}_{2}\right.$ DCF-DA， 2',7'-dichlorodihydrofluorescein diacetate, $1 \mu \mathrm{M}$ ) according to the method described earlier (Lyubushkina et al., 2014a). Briefly, $100 \mu \mathrm{L}$ of culture was placed in $2 \mathrm{~mL}$ microcentrifuge tubes, and incubated for $10 \mathrm{~min}$ at $26^{\circ} \mathrm{C}$ (control) or at $45,50,55$ or $60^{\circ} \mathrm{C}$ (for heat treatments) with the addition of dye on a TS-100 mini thermal shaker.

For qualitative visualisation of the $\Delta \Psi_{\mathrm{m}}$, we used the potential-dependent fluorescent cationic sensor JC-1 (5.5'.6.6'-tetrachloro-1.1'.2.2'tetraethylbenzimidazolo-carbocyanine, $20 \mu \mathrm{M}$ ) according to the method described previously (Lyubushkina et al., 2014a). Briefly, $100 \mu \mathrm{L}$ of the culture was placed in $2 \mathrm{~mL}$ microcentrifuge tubes. Then $100 \mu \mathrm{L}$ of staining buffer $(25 \mathrm{mM}$ MES, $2 \%$ glycerol, pH 5.5) was added and the mixture was incubated for $10 \mathrm{~min}$ at $26{ }^{\circ} \mathrm{C}$ (control) or at $45,50,55$ or $60^{\circ} \mathrm{C}$ (heat treatments) with the addition of dye.

In some experiments studying ROS and $\Delta \Psi_{\mathrm{m}}$ in $S$. officinarum cell culture we used carbonyl cyanide m-chlorophenyl hydrazine (CCCP, $20 \mu \mathrm{M}$ ), which is a protonophore, and is used to detect mitochondrial participation in ROS and $\Delta \Psi_{\mathrm{m}}$ generation processes.

\section{Cell respiration analysis}

The rate of oxygen uptake by the S. officinarum suspension culture cells was measured at $26{ }^{\circ} \mathrm{C}$ using the «Oxytherm» 
system (Hansatech Instruments, Great Britain) with a Clark-type oxygen electrode. We used a sequential addition of potassium cyanide $(1.2$ $\mathrm{mM}, \mathrm{KCN}$, an inhibitor of cytochrome $c$ oxidase) and benzhydroxamic acid ( $3 \mathrm{mM}$, BHAM, an inhibitor of cyanide-resistant alternative oxidase) to measure the $\mathrm{CP}$ and AP capacities, respectively. The oxygen uptake recorded after addition of inhibitors was considered nonspecific and was not included in the respiratory activity. The optimal concentrations of inhibitors were determined by titrating the suspension cell culture with increasing concentrations of the inhibitors to saturate the $\mathrm{O}_{2}$ uptake. The oxygen concentration in air-saturated water at $26^{\circ} \mathrm{C}$ was assumed to be $253 \mu \mathrm{M}$. The respiration rate of cells was calculated as $\mathrm{nmol} \mathrm{O}_{2} /(\mathrm{g}$ fresh weight $(\mathrm{FW}) \times \min )$.

\section{Statistical analysis}

At least three independent experiments were performed with 2-8 repeats. Data are presented as medians $\left(\mathrm{Q}_{50}\right)$ and error bars are the $\mathrm{Q}_{25}$ and $\mathrm{Q}_{75}$ percentiles. To visualise ROS content and $\Delta \Psi_{\mathrm{m}}$ data we used a box-and-whiskers diagram. The line in the «box» is $\mathrm{Q}_{50}$, and the borders of the «box» limit the interquartile range between $\mathrm{Q}_{25}$ and $\mathrm{Q}_{75}$. The «whiskers» represent maximum and minimum values. The Shapiro-Wilk test was used as the normality test. Kruskal-Wallis one-way analysis of variance on ranks was used. All pairwise multiple comparison procedures were performed using Dunn's method ( $\mathrm{n}=$ 3-10). Significant differences $(p<0.05)$ at $\mathrm{Q}_{50}$ are marked with different letters next to the corresponding point or the column on the graphs.

\section{Results}

High temperatures induce cell death in S. officinarum suspension culture

There were $80-85 \%$ of cells alive in the $S$. officinarum suspension culture at the $\log$ phase. We did not observe statistically significant changes to the proportion of living cells in the culture after exposure at $45{ }^{\circ} \mathrm{C}$ for 10 and 30 min (Fig. 1a, b). Exposure of the S. officinarum suspension culture at $50{ }^{\circ} \mathrm{C}$ activated a prolonged process of cell death, lasting all four days of the experiment. About $30-35 \%$ of the cells in the culture remained alive by the end of this period (Fig. $1 \mathrm{a}, \mathrm{b}$ ). It should be noted that the length of time the $S$. officinarum culture was treated at $50{ }^{\circ} \mathrm{C}$ for did not affect the intensity of the process of cell death (Fig. 1a, b). Exposure at $55{ }^{\circ} \mathrm{C}$ for 10 min caused an extensive process of cell death. About $30 \%$ of cells remained alive in the culture immediately after the treatment (Fig. 1a). We did not observe any further cell death in the culture for the next two days. However, all the cells in the culture were dead after four days of treatment (Fig. 1a). Increasing exposure at $55^{\circ} \mathrm{C}$ to $30 \mathrm{~min}$ turned out to be critical, as no more than $5 \%$ of cells remained alive in the $S$. officinarum culture immediately after exposure (Fig. 1b). The effect of treatment at $60{ }^{\circ} \mathrm{C}$ (for 10 and $30 \mathrm{~min}$ ) was similar, as only $3-5 \%$ of the cells remained alive in the culture following treatment (Fig. 1a, b).

We can conclude that treatment at $45{ }^{\circ} \mathrm{C}$ was insufficient to cause irreversible damage in the S. officinarum cells, while the treatments at 55 and $60{ }^{\circ} \mathrm{C}$ were too extreme for the cells to form an adequate response. Treatment at $50{ }^{\circ} \mathrm{C}$ did not cause immediate cell death, however, the changes in cell metabolism were so significant that there was a process of cell death in the culture for four days following this treatment.

Changes in ROS levels and $\triangle \Psi_{m}$ in $S$. officinarum cells under the influence of high temperatures

All the high temperatures tested caused a significant increase in ROS levels in the S. officinarum cells (Fig. 2a, b). It was found that increasing the exposure time from 10 to $30 \mathrm{~min}$ 

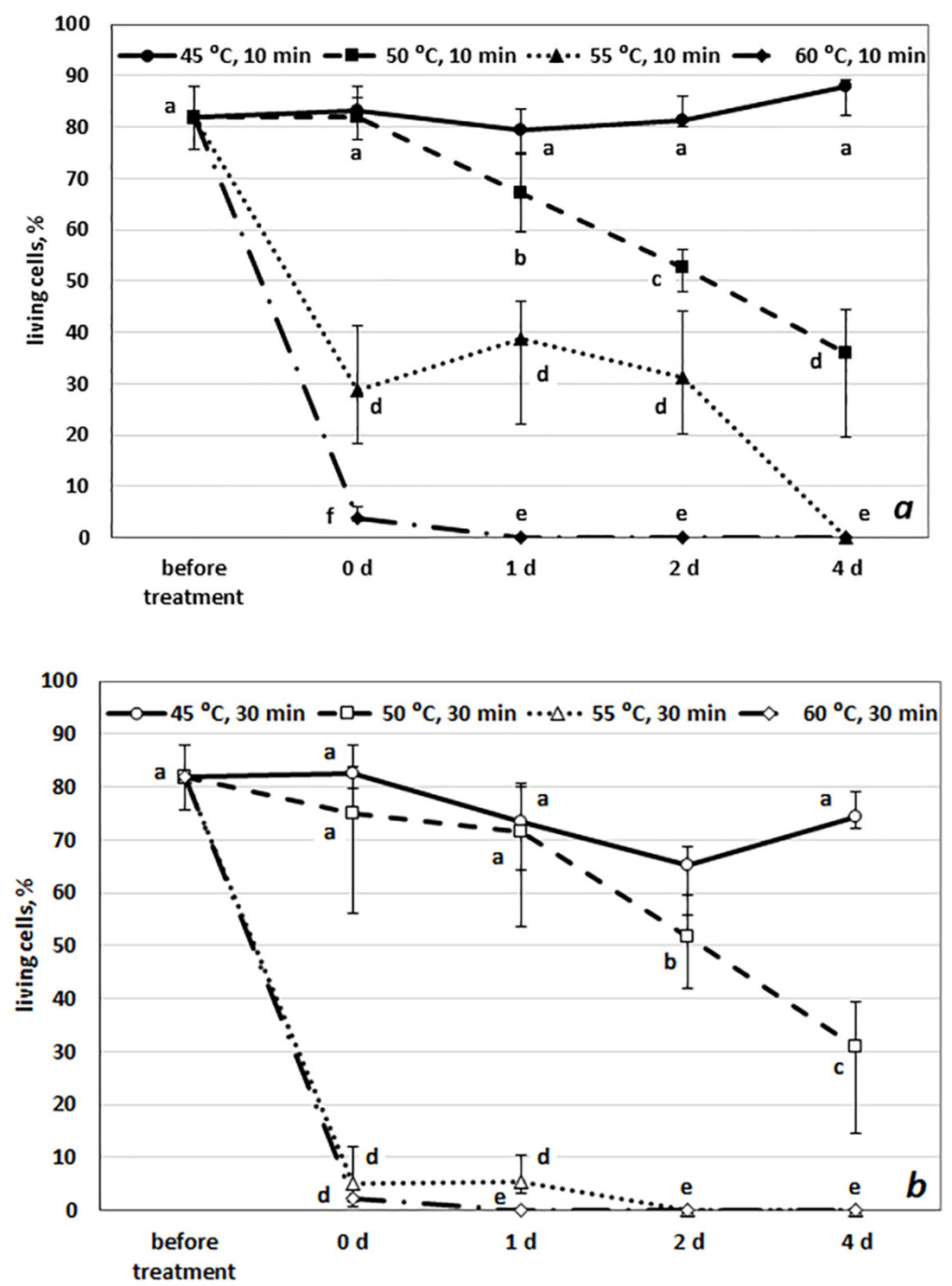

Fig. 1. Cell death processes in the S. officinarum suspension culture induced by high temperatures treatments for $10(a)$ or $30 \mathrm{~min}(b)$. The figure shows the median $\left(\mathrm{Q}_{50}\right)$ and the error bars are the $\mathrm{Q}_{25}$ and $\mathrm{Q}_{75}$ percentiles $(\mathrm{n}=5$, $p<0.05)$

at 45 and $50{ }^{\circ} \mathrm{C}$ leads to a further increase in ROS production in the cells (Fig. 2a, b). We detected a four-fold increase in DCF fluorescence intensity in the cells under all high temperature conditions. Increasing the exposure time from 10 to $30 \mathrm{~min}$ at $55{ }^{\circ} \mathrm{C}$ did not increase the ROS production in the cells (Fig. 2a, b). The treatment of the cell culture at $60{ }^{\circ} \mathrm{C}$ for $30 \mathrm{~min}$ led to a decrease in DCF fluorescence intensity, compared with the treatment of the culture at $60{ }^{\circ} \mathrm{C}$ for $10 \mathrm{~min}$. It should be noted that ROS levels in the cells after the most severe heat exposure $\left(60^{\circ} \mathrm{C}\right.$ at $\left.30 \mathrm{~min}\right)$ did not significantly differ from those in the control cells (Fig. 2a, b).

The study of $\Delta \Psi_{\mathrm{m}}$ using the JC-1 fluorescent probe showed that there were mitochondria with both high and low $\Delta \Psi_{\mathrm{m}}$ in the control cells. This was proved by the fluorescence of JC-1 monomers 

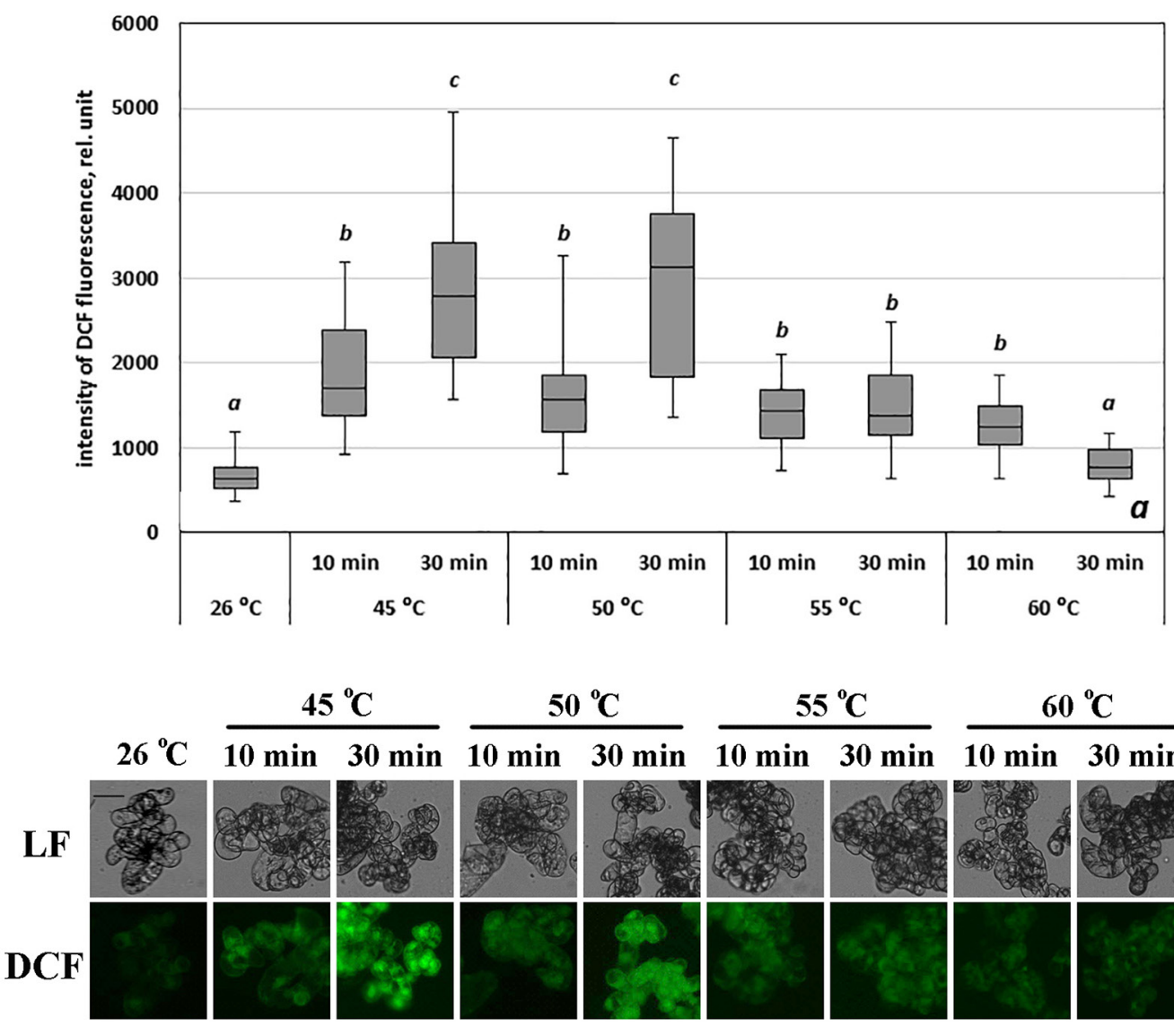

$50{ }^{\circ} \mathrm{C}$

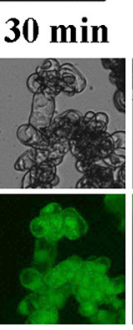

$55^{\circ} \mathrm{C}$

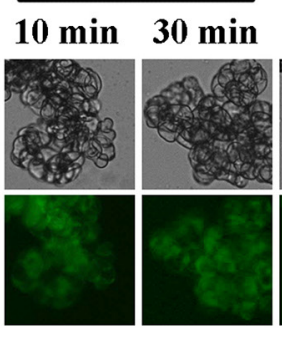

$60{ }^{\circ} \mathrm{C}$

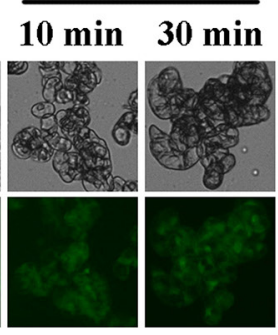

Fig. 2. ROS levels in the cells of the $S$. officinarum suspension culture under high temperature treatments: $a$-data counting $(\mathrm{n}=5, p<0.05) ; b$ - microphotograph of the $S$. officinarum cells. The line in the «box» is $\mathrm{Q}_{50}$, the borders of the «box» limit the interquartile range between $\mathrm{Q}_{25}$ and $\mathrm{Q}_{75}$ and the «whiskers» present maximum and minimum values; rel. unit - relative units; $26^{\circ} \mathrm{C}$ - control conditions; 45, 50, 55 and $60{ }^{\circ} \mathrm{C}$ - treatment temperature; 10 and $30 \mathrm{~min}$ - treatment exposure, $\mathrm{LF}$ - light field; DCF - 2,7-dichlorodihydrofluorescein diacetate, $1 \mu \mathrm{M}$; bar $50 \mu \mathrm{m}$

in the green spectral region and J-aggregates in the red spectral region (Fig. 3b). A statistically significant increase in the red fluorescence in the cells occurred only under short-term high temperature treatments for $10 \mathrm{~min}$ (Fig. 3a, b). Prolonged high temperature influence caused depolarisation of the inner mitochondrial membrane and almost complete disappearance of JC-1 red fluorescence in the S. officinarum cells (Fig. 3a, b). There was no red fluorescence and therefore an $\Delta \Psi_{\mathrm{m}}$ increase in the cells of the S. officinarum suspension culture that had been exposed at $60^{\circ} \mathrm{C}$ (Fig. 3a, b).

\section{ROS production in S. officinarum suspension} culture cells under high temperature conditions is caused by changes in mitochondrial activity

In order to determine how the ROS increase caused by high temperature treatments in $S$. officinarum cells is associated with mitochondrial activity, we used the carbonyl cyanide m-chlorophenyl hydrazine (CCCP, $20 \mu \mathrm{M})$. This compound is a protonophore and it uncouples oxidative phosphorylation in mitochondria. As a result, $\Delta \Psi_{\mathrm{m}}$ on the inner mitochondrial membrane decreases. In this 

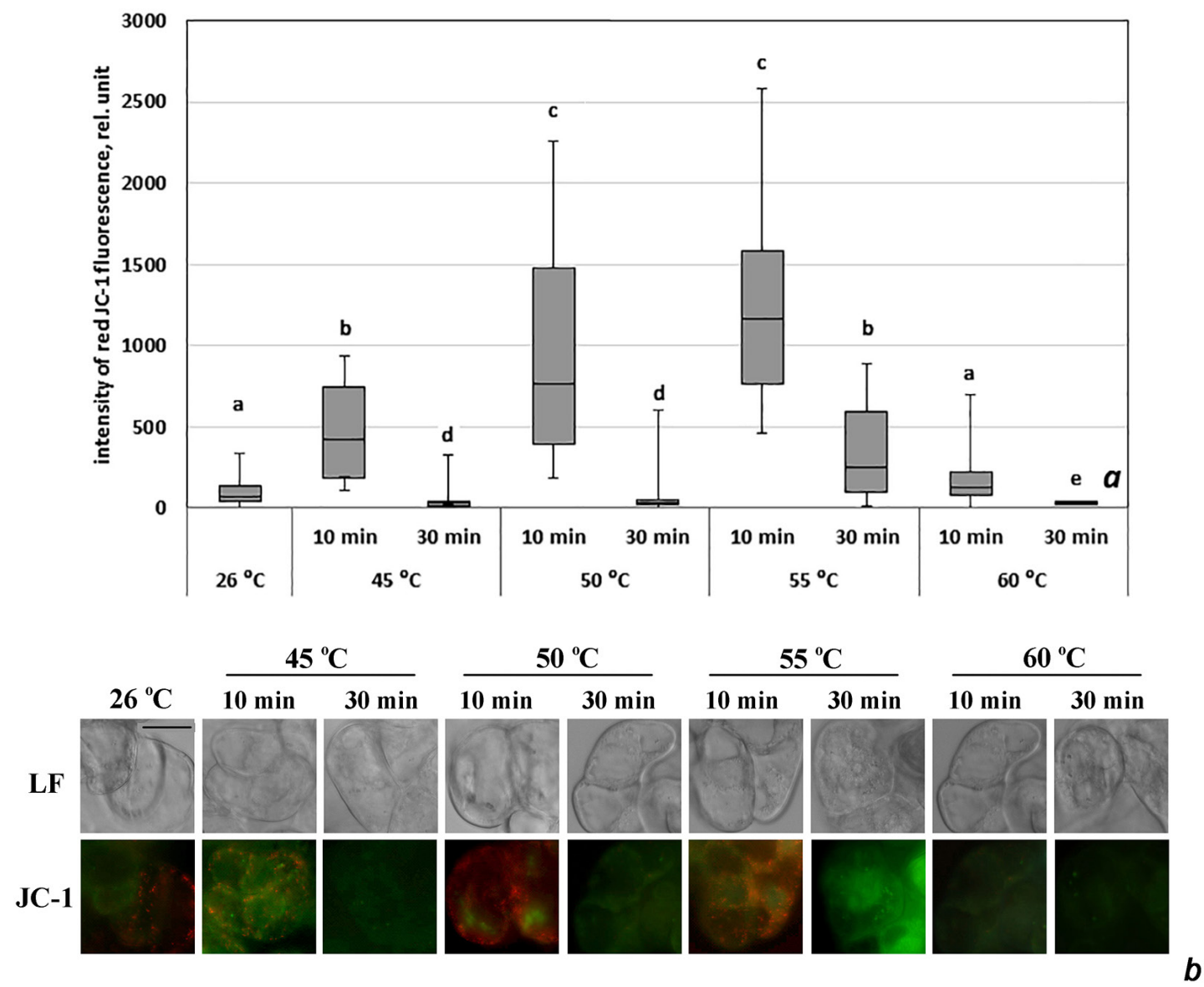

Fig. 3. $\Delta \Psi_{\mathrm{m}}$ in cells of the S. officinarum suspension culture under high temperature treatments: $a-$ red fluorescence data counting $(\mathrm{n}=5, p<0.05) ; b$ - microphotograph of the $S$. officinarum cells with green and red fluorescence. JC-1-5.5'.6.6'-tetrachloro-1.1'.2.2'-tetraethylbenzimidazolo-carbocyanine, $20 \mu \mathrm{M}$. Other designations correspond to Fig. 2

experiment, we only gave the high temperature treatment for $10 \mathrm{~min}$ (at 45, 50 and $55^{\circ} \mathrm{C}$ ), which caused both $\Delta \Psi_{\mathrm{m}}$ and ROS content in the $S$. officinarum cells to increase. It was shown that the addition of CCCP to the culture during exposure to high temperatures prevented hyperpolarisation of the inner mitochondrial membrane, and red fluorescence of the J-aggregates was not observed (Fig. 4). To study the effect of CCCP on the ROS levels in the cells, it was added during the high temperature treatments, together with a DCF fluorescent probe. It was found that the ROS levels in S. officinarum cells were statistically significantly lower when the cells were simultaneously treated with high temperatures and CCCP, compared with only being given the high temperature treatment (Fig. 4). We can conclude that ROS production in $S$. officinarum cells under high temperature conditions was partially caused by changes in mitochondrial activity.

\section{Changes to respiratory activity}

and AP contribution in S. officinarum

suspension culture cells

under high temperature treatments

The S. officinarum culture had a high respiratory rate under the control conditions 

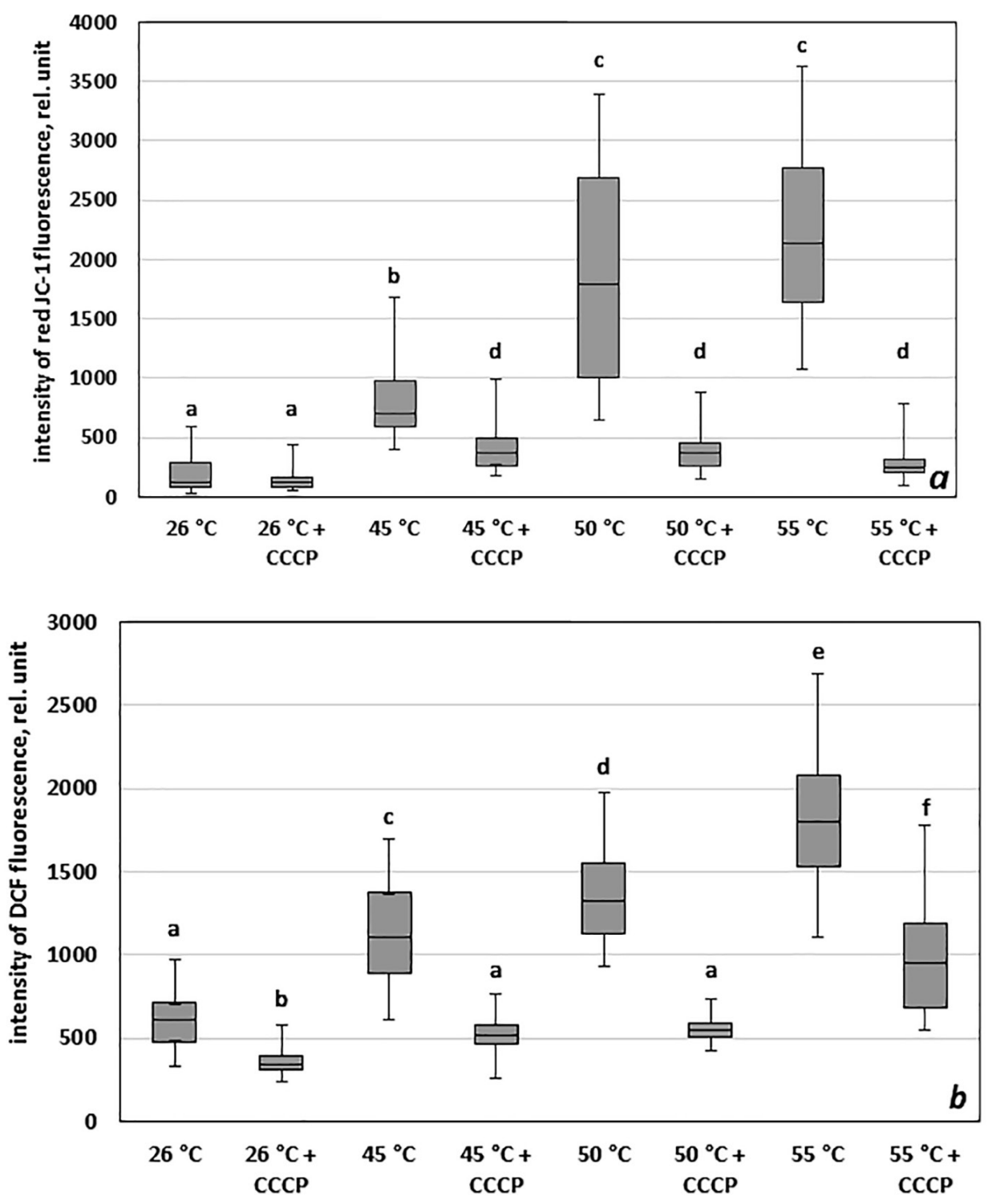

Fig. 4. $\Delta \Psi_{\mathrm{m}}(a)$ and the ROS level $(b)$ in cells of the $S$. officinarum suspension culture during exposure to high temperatures for $10 \mathrm{~min}$ with the addition of carbonyl cyanide $\mathrm{m}$-chlorophenyl hydrazine $(\mathrm{CCCP}) .26^{\circ} \mathrm{C}-\mathrm{control}$ conditions; 45,50 and $55{ }^{\circ} \mathrm{C}$ - temperature treatments without $\mathrm{CCCP}$ addition; $45{ }^{\circ} \mathrm{C}+\mathrm{CCCP}, 50{ }^{\circ} \mathrm{C}+\mathrm{CCCP}$ and $55^{\circ} \mathrm{C}+\mathrm{CCCP}$ - temperature treatments with CCCP addition, $5 \mu \mathrm{M}$. The line in the «box» is $\mathrm{Q}_{50}$, the borders of the «box» limit the interquartile range between $\mathrm{Q}_{25}$ and $\mathrm{Q}_{75}$, and the «whiskers» present maximum and minimum values $(\mathrm{n}=3-5, p<0.05)$; rel.unit - relative units

(about $3000 \mathrm{nmol} \mathrm{O}_{2} /(\mathrm{g} \mathrm{FW} \times \mathrm{min})$ (Fig. 5a). The contribution of AP to the respiratory rate of $S$. officinarum cells was very significant. At the beginning of the experiment it was about $30 \%$, increasing to $40 \%$ after one day (Fig. 5a, b). All the high temperature treatments resulted in a statistically significant reduction in the respiratory rate of the culture immediately following exposure (Fig. 5a). This reduction was mainly due to a decrease in CP activity (Fig. 5a). We observed a significant decrease in respiratory electron transport via AP only under the most severe high temperature exposure $\left(55^{\circ} \mathrm{C}\right.$ for 30 min and $60{ }^{\circ} \mathrm{C}$ for $10 \mathrm{~min}$, Fig. 5a). Treatment 

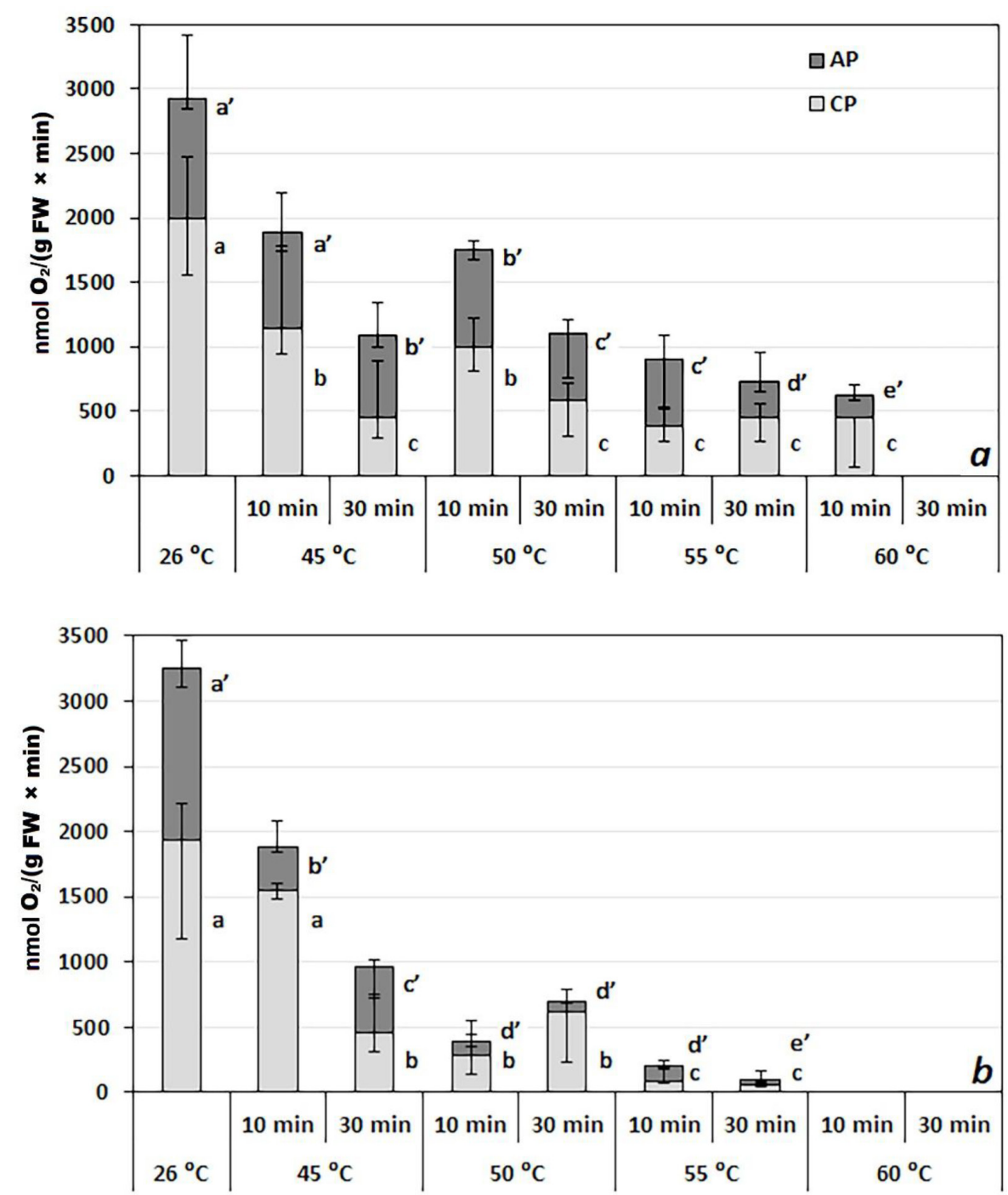

Fig. 5. Cyanide-sensitive (CP) and cyanide-resistant (AP) respiration in cells of the S. officinarum suspension culture after the high temperature treatments: $a$ - immediately after the treatments; $b$ - one day after the treatments. $26^{\circ} \mathrm{C}$ - control conditions, $45,50,55$ and $60{ }^{\circ} \mathrm{C}$ - temperature treatments; 10 and 30 min - treatment exposure. The figure shows the median $\left(\mathrm{Q}_{50}\right)$ and the error bars are the $\mathrm{Q}_{25}$ and $\mathrm{Q}_{75}$ percentiles $(\mathrm{n}=5-10, p<0.05)$

of the culture at $60{ }^{\circ} \mathrm{C}$ for $30 \mathrm{~min}$ led to almost complete cell death and it was not possible to register respiration.

We obtained an interesting result analysing the respiratory rate of a $S$. officinarum culture treated at $45{ }^{\circ} \mathrm{C}$. This exposure (for 10 and 30 min) did not cause cell death (Fig. 1a, b). Nevertheless, we observed a stable decrease in the respiratory activity of the cells throughout the experiment. It was 1.5 times lower than the control after 10 minutes of treatment (Fig. 5a, b). A 30-minute exposure had a more serious effect on cell respiration. The respiratory rate decreased by three times both immediately and after one day following treatment at $45{ }^{\circ} \mathrm{C}$ (Fig. 5a, b). It should also be noted that there was a predominant decrease in AP contribution to cell respiratory activity one day after treatment at $45{ }^{\circ} \mathrm{C}$ for 10 min up to about $18 \%$ (Fig. 5b). 
The changes caused by treatment at $50{ }^{\circ} \mathrm{C}$ to the respiratory activity of $S$. officinarum cells were also quite remarkable. This treatment had already led to a more significant decrease in the respiratory rate of $S$. officinarum cells than treatment at $45{ }^{\circ} \mathrm{C}$, at one day posttreatment (Fig. 5b). The contributions of AP to respiration were also lower than the control at the corresponding period (29 and $11 \%$ after 10 and $30 \mathrm{~min}$ of treatment, respectively, Fig. 5b). Particular attention should be paid to the fact that the decrease in respiration after exposure at $50{ }^{\circ} \mathrm{C}$ occurred faster than the process of cell death in the culture. Therefore, an interruption in respiratory activity preceded cell death (Fig. 1a, $\mathrm{b}$ and Fig. 5a, b). Treatments of the S. officinarum culture at 55 and $60{ }^{\circ} \mathrm{C}$ were so severe that they led to a complete interruption of cell respiration after only one day post-exposure (Fig. 5b).

It can be concluded that high temperatures influenced the respiratory rate of $S$. officinarum cells, even in the cases where we did not notice any negative effects on survival following treatment. Respiratory activity was critical for the formation of a cellular response to high temperature stress, and AP activity was the most stable under stress conditions.

\section{Discussion}

S. officinarum is an important agricultural plant belonging to the cereal or bluegrass family (Gramineae or Roaceae). Its region of origin is considered to be New Guinea (Daniels, Daniels, 1993). S. officinarum is a typical tropical plant and it has a sufficiently high level of resistance to high temperatures. Its optimum growth temperature is $30^{\circ} \mathrm{C}$. Due to this, we used temperatures that significantly exceeded the optimum to create high-temperature stress.

An increase in ROS in cells under the influence of high temperatures is one of the common responses of plants to stress. It has been shown that heat shock leads to an increase in ROS production in Arabidopsis, tobacco and winter wheat cells (Vacca et al., 2004; Zhang et al., 2009; Fedyaeva et al., 2014). In our earlier studies, we had also observed an increase in the formation of ROS in $S$. officinarum cells during short-term heat exposure (Lyubushkina et al., 2014b). It should be noted that ROS are products of normal plant metabolism and serve to regulate a wide range of processes, including growth and development. They also participate in the formation of plant responses to external influences (Katano et al., 2018). However, if unbalanced by scavenging processes, an increase in ROS production can cause irreversible damage to cells and lead to their death. In this study, we observed an increase in ROS production in all cases of heat treatment, except for at $60{ }^{\circ} \mathrm{C}$ for $30 \mathrm{~min}$ (Fig. 2a, b). In the latter case, the stress factor was so acute that all the cells had already died during exposure (Fig. 1b). Although other temperatures intensified ROS formation in $S$. officinarum cells, they did not always lead to cell death. We observed an increase in ROS levels after heat exposure at $45^{\circ} \mathrm{C}$, but cell death did not occur, either at the time of exposure or during the next four days (Fig. 1a, b and Fig. 2a, b). A similar increase in ROS production in $S$. officinarum cells was observed after heat exposure at $50{ }^{\circ} \mathrm{C}$, and there was a process of prolonged cell death in the culture for the four days following treatment. Treatment at $55{ }^{\circ} \mathrm{C}$ also caused an increase in ROS levels in the cells, but the cell death caused at this temperature was much greater and occurred in a shorter period of time (Fig. 1a, b and Fig. 2a, b). Accordingly, we can conclude that under stress, ROS can trigger completely different response patterns in plant cells. Since implementing both adaptive mechanisms and PCD are energy consuming processes (Bras et al., 2005), it can be assumed that the realisation of these patterns depends on 
the degree of mitochondrial damage by stress factors and their functional activity.

Fedyaeva et al. (2014) demonstrated the dependence of ROS levels in winter wheat cells on oxidative phosphorylation coupling under heat shock. CCCP prevented the hyperpolarisation of the inner mitochondrial membrane as well as ROS production (Fedyaeva et al., 2014). In our study, CCCP led to similar results (Fig. 4a, b). It should be noted that a decrease in DCF fluorescence intensity in the presence of CCCP does not occur at the control level, since processes associated with ROS production are not only present in mitochondria, but also in endoplasmic reticulum, peroxisomes and cytosol in a plant heterotrophic cell under stress (Katano et al., 2018).

The question is what changes in the function of plant mitochondria lead to subsequent cell death due to a critical increase in ROS levels? Our results suggest that it is important for the neighbouring cell to maintain respiratory intensity for the first day following stress exposure (Fig. 5b). Exposure at $45{ }^{\circ} \mathrm{C}$ (for 10 and $30 \mathrm{~min}$ ) did not lead to cell death (Fig. 1a, b). The rate of cell respiration did not fall below $1000 \mathrm{nmol} \mathrm{O}_{2} /(\mathrm{g} \mathrm{FW} \times \mathrm{min})$ in these cases (Fig. 5b). CP contribution increased to $90 \%$ one day after treatment at $45{ }^{\circ} \mathrm{C}$ for 10 min (Fig. 5b). It can be assumed that the cells successfully scavenged increased ROS levels, and the ROS served as signalling molecules for cell reprogramming, triggering synthesis of the corresponding compounds necessary for acclimatisation (Kohli et al., 2019).

Treatment at $50{ }^{\circ} \mathrm{C}$ caused a prolonged process of cell death in the $S$. officinarum culture, and we observed a decrease in respiratory activity. However, this temperature did not significantly affect AOX activity, as AP contribution fell by $11 \%$ compared with the control one day after the 30-min exposure (Fig. 5a, b). It is likely that this stability of AOX activity was necessary for the realisation of the PCD program in the culture. Borovik and Grabelnych (2018) showed that AP contribution increased in green winter wheat plants under the influence of high temperatures. This caused ROS levels to reduce in the mitochondria and chloroplasts (Borovik, Grabelnych, 2018). Our results are consistent with data obtained by Robson and Vanlerberghe (2002) using AS8 transgenic tobacco culture. They showed that the role of AOX in cell susceptibility to PCD is its ability to permanently weaken mitochondrial ROS production, preventing oxidative damage to cells. Regarding the highest temperatures that caused extensive cell death $\left(55\right.$ and $\left.60{ }^{\circ} \mathrm{C}\right)$, cell damage (including the mitochondria) was so great that the respiratory rate had already dramatically decreased during the treatment. Following this, there was an extensive and uncontrolled process of cell death (Fig. 1a, b; Fig. 5a, b).

\section{Conclusion}

In conclusion, while a plant cell under high temperature stress is able to provide for its increased energy needs and at the same time effectively limit the increase in ROS production, nothing threatens it. In this case the role of ROS is limited by the regulation of metabolism and serves to benefit the cell, providing a balanced formation of acclimation reactions. However, as soon as this balance shifts towards excessive ROS production, the respiratory ETC is destroyed, which entails subsequent disturbances of the entire cellular metabolism and ultimately leads to cell death. 


\section{References}

Bartoli C. G., Gomez F., Gergoff G., Guiamét J.J., Puntarulo S. (2005) Up-regulation of the mitochondrial alternative oxidase pathway enhances photosynthetic electron transport under drought conditions. Journal of Experimental Botany, 56(415): 1269-1276

Baena-González E., Sheen J. (2008) Convergent energy and stress signaling. Trends in Plant Science, 13(9): 474-482

Borovik O.A., Grabelnych O.I. (2018) Mitochondrial alternative cyanide-resistant oxidase is involved in an increase of heat stress tolerance in spring wheat. Journal of Plant Physiology, 231: 310-317

Bras M., Queenan B., Susin S.A. (2005) Programmed cell death via mitochondria: different modes of dying. Biochemistry (Moscow), 70(2): 231-239

Daniels J., Daniels C. (1993) Sugarcane in Prehistory. Archaeology in Oceania, 28: 1-7

Djanaguiraman M., Boyle D.L., Welti R., Jagadish S. V.K., Prasad P.V.V. (2018) Decreased photosynthetic rate under high temperature in wheat is due to lipid desaturation, oxidation, acylation, and damage of organelles. BMC Plant Biology, 18: 55

Dmitrieva S. A., Ponomareva A. A., Gurjanov O.P., Mazina A. B., Andrianov V.V., Iyudin V. S., Minibayeva F. V. (2018) Spermine induces autophagy in plants: possible role of NO and reactive oxygen species. Doklady Biochemistry and Biophysics, 483(1): 341-343

Fedyaeva A.V., Stepanov A.V., Lyubushkina I.V., Pobezhimova T.P., Rikhvanov E. G. (2014) Heat shock induces production of reactive oxygen species and increases inner mitochondrial membrane potential in winter wheat cells. Biochemistry (Moscow), 79(11): 1202-1210

Grabelnych O.I., $\quad$ Borovik O.A., Tauson E.L., $\quad$ Pobezhimova T.P., $\quad$ Katyshev A.I., Pavlovskaya N. S., Koroleva N. A., Lyubushkina I. V., Bashmakov V. Y., Popov V.N., Borovskii G. B., Voinikov V.K. (2014) Mitochondrial energy-dissipating systems (alternative oxidase, uncoupling proteins, and external NADH dehydrogenase) are involved in development of frost-resistance of winter wheat seedlings. Biochemistry (Moscow), 79(6): 506-519

Graether S.P., Boddington K.F. (2014) Disorder and function: a review of the dehydrin protein family. Frontiers in Plant Science, 5: 576

Katano K., Honda K., Suzuki N. (2018) Integration between ROS regulatory systems and other signals in the regulation of various types of heat responses in plants. International Journal of Molecular Sciences, 19(11): 3370

Kohli S. K., Khanna K., Bhardwaj R., Abd Allah E.F., Ahmad P., Corpas F. J. (2019) Assessment of subcellular ROS and NO metabolism in higher plants: multifunctional signaling molecules. Antioxidants, 8(12): 641

Kolupaev Yu. Ye., Karpets Yu.V. (2009) Reactive oxygen species at adaptation of plants to stress temperatures. Physiology and Biochemistry of Crop Plants [Fiziologiya i biokhimiya kul'turnykh rasteniy], 41(2): 95-108 (in Russian)

Lyubushkina I.V., Grabelnych O.I., Pobezhimova T.P., Stepanov A.V., Fedyaeva A.V., Fedoseeva I. V., Voinikov V.K. (2014a) Winter wheat cells subjected to freezing temperature undergo death process with features of programmed cell death. Protoplasma, 251(3): 615-623

Lyubushkina I. V., Fedyaeva A. V., Pobezhimova T.P., Stepanov A. V., Rikhvanov E. G. (2014b) Activation of cell death in the Sugar Cane suspension culture by the exposure to high temperature. Journal of Stress Physiology and Biochemistry, 10(4): 13-24 (in Russian)

$$
-367-
$$


Martí M.C., Olmos E., Calvete J. J., Díaz I., Barranco-Medina S., Whelan J., Lázaro J. J., Sevilla F., Jiménez A. (2009) Mitochondrial and nuclear localization of a novel pea thioredoxin: identification of its mitochondrial target proteins. Plant Physiology, 150(2): 646-657

Morgan M.J., Lehmann M., Schwarzländer M., Baxter C.J., Sienkiewicz-Porzucek A., Williams T. C.R., Schauer N., Fernie A. R., Fricker M.D., Ratcliffe R. G., Sweetlove L. J., Finkemeier I. (2008) Decrease in manganese superoxide dismutase leads to reduced root growth and affects tricarboxylic acid cycle flux and mitochondrial redox homeostasis. Plant Physiology, 147(1): 101-114

Møller I. M. (2001) Plant mitochondria and oxidative stress: electron transport, NADPH turnover, and metabolism of reactive oxygen species. Annual Review of Plant Physiology and Plant Molecular Biology, 52: 561-591

Nguyen H.T.H., Umemura K., Kawano T. (2016) Indole-3-acetic acid-induced oxidative burst and an increase in cytosolic calcium ion concentration in rice suspension culture. Bioscience, Biotechnology, and Biochemistry, 80(8): 1546-1554

Nievola C.C., Carvalho C.P., Carvalho V., Rodrigues E. (2017) Rapid responses of plants to temperature changes. Temperature, 4(4): 371-405

Noctor G., De Paepe R., Foyer C.H. (2007) Mitochondrial redox biology and homeostasis in plants. Trends in Plant Science, 12(3): 125-134

Popov V.N. (2014) Feedback loop of non-coupled respiration and reactive oxygen species production in plant mitochondria. Reactive oxygen and nitrogen species signaling and communication in plants. Gupta K. J., Igamberdiev A. U. (eds.) Switzerland, Springer International Publishing, p. 79-88

Rikhvanov E.G., Gamburg K.Z., Varakina N.N., Rusaleva T.M., Fedoseeva I. V., Tauson E.L., Stupnikova I. V., Stepanov A. V., Borovskii G. B., Voinikov V. K. (2007) Nuclear-mitochondrial crosstalk during heat shock in Arabidopsis cell culture. Plant Journal, 52(4): 763-778

Robson C. A., Vanlerberghe G.C. (2002) Transgenic plant cells lacking mitochondrial alternative oxidase have increased susceptibility to mitochondria-dependent and -independent pathways of programmed cell death. Plant Physiology, 129(4): 1908-1920

Sieger S.M., Kristensen B.K., Robson C.A., Amirsadeghi S., Eng E.W.Y., Abdel-Mesih A., Møller I.M., Vanlerberghe G.C. (2005) The role of alternative oxidase in modulating carbon use efficiency and growth during macronutrient stress in tobacco cells. Journal of Experimental Botany, 56(416): 1499-1515

Tripathi D., Nam A., Oldenburg D. J., Bendich A. J. (2020) Reactive oxygen species, antioxidant agents, and DNA damage in developing maize mitochondria and plastids. Frontiers in Plant Science, 11: 596

Vacca R. A., De Pinto M.C., Valenti D., Passarella S., Marra E., De Gara L. (2004) Production of reactive oxygen species, alteration of cytosolic ascorbate peroxidase, and impairment of mitochondrial metabolism are early events in heat shock-induced programmed cell death in tobacco Bright-Yellow 2 cells. Plant Physiology, 134(3): 1100-1112

Vanlerberghe G.C. (2013) Alternative oxidase: a mitochondrial respiratory pathway to maintain metabolic and signaling homeostasis during abiotic and biotic stress in plants. International Journal of Molecular Sciences, 14(4): 6805-6847

Vierling E. (1991) The roles of heat shock proteins in plants. Annual Review of Plant Physiology and Plant Molecular Biology, 42: 579-620 
Wanniarachchi V.R., Dametto L., Sweetman C., Shavrukov Yu., Day D.A., Jenkins C.L.D., Soole K. L. (2018) Alternative respiratory pathway component genes ( $A O X$ and $N D)$ in rice and barley and their response to stress. International Journal of Molecular Sciences, 19(3): 915

Zavala-Ortiz D.A., Ebel B., Guedon E., Marc A., Barradas-Dermitz D.M., Hayward-Jones P.M., Aguilar-Uscanga M.G. (2020) In situ cell differentiation monitoring of Catharanthus roseus suspension culture processes by NIR spectroscopy. Bioprocess and Biosystems Engineering, 43(4): 747-752

Zhang L., Li Y., Xing D., Gao C. (2009) Characterization of mitochondrial dynamics and subcellular localization of ROS reveal that HsfA2 alleviates oxidative damage caused by heat stress in Arabidopsis. Journal of Experimental Botany, 60(7): 2073-2091 